\title{
Effectiveness of Concept Mapping Strategy on Understanding and Retention among Secondary School Students
}

Ramyasmruthi S Talanki*

\section{Abstract:}

Concept mapping is a tool used for representing knowledge in an organized format. It consists of concepts that are encircled and a connecting line with linking words or phrases represents the relationships between the different sub-concepts. Joseph D. Novak developed the concept maps in the 1970s. Mendia et al., 2008 have used this tool that promotes meaningful learning in math with secondary school students. Sharma, 2014 has used this tool for student's achievement and concept retention for higher secondary student. This paper is regarding effectiveness of concept maps in concept retention among secondary school students. It is an action research conducted with ten students. The concept map was prepared using software called as Cmap. The institute that has developed this software is Institute for Human and Machine Cognition. The concept of structure of DNA was taken to teach the students using concept map. A pretest, posttest, and delayed test were conducted to observe the students understanding and retention of the concept. The results were analyzed using SPSS software. It was observed that the understanding and retention of

* School of Education, Christ University, Bengaluru, Karnataka, India; ramysmruthi.talanki@ed.christuniverity.in 
the concept among the students was visible after using the concept mapping strategy.

Keywords: concept maps, teaching strategy, retention, Cmap software, secondary school students, Biology and understanding

\section{Introduction:}

Several strategiesare used for teaching biology at the secondary school level, the most common strategy is the lecture method, where the teacher lectures on the concepts to the students. The strategy which is used exclusively for teaching of biology is "Structural and functional approach," where the teacher divides the board into three sections, first section is used to draw the diagram, second section to label the diagram and the third section for writing the functions of each part labeled in the diagram.

Novak suggested a new technique, which would help the students to organize the concepts they learned. The methodwas called as Concept mapping. When the student create/ draws a conceptmap, they can reorganize newly acquired concepts with the existing ones in a hierarchical network.

Novak and Gowin (1981) described the concept as "regularities in events or objects which are designated by sign or symbol." In concepts map, the concepts are connected to each other through connecting lines which define propositions or particular relationship between the concepts. By constructing such maps, students can figure out the different relationships that can exists between concepts, which increases their understanding of the subject.

It has been observed that when concept mapping is used as a classroom technique, it enhances the learning in science subjects. Recent development shows that concept mapping is a metacognitive tool as it promotes the understanding in which new knowledge interacts with students' existing knowledge. This interaction will be easier if existing knowledge is made clear to both student and teacher. This is called as 'meaningful learning.'

Construction of the map does mean whether the author can reproduce the knowledge learned, but it shows the perception of 
the author (Jonassen et al., 1997). A concept map is unique to the author and it represents two properties of understanding namely representation and organization of ideas. Johnson-Laird (1983) has suggested that there are three kinds of representations: "propositional representations which are strings of symbols that correspond to natural language, mental models which are structural analogies of the world, and images which are the perceptual correlates of models from a particular point of view" (Kinchin and Hay, 2000).

Nesbit and Adesope (2006), conducted an experimental and quasiexperimental study where the students used concept maps and knowledge maps for learning. They were given the freedom to construct, modify and view the node linking of the maps. The students ranged from Grade 4 to graduate students in various domains like science, psychology, statistics and nursing. From the study it was determined that the concept mapping strategy was effective in attaining the knowledge and transfer of knowledge, when compared to reading texts, taking notes or participation in class discussions. The study also showed that the use of animated maps the retention of the knowledge was more when compared to hyperlinked maps. It was also observed that for dyadic learning and cooperative learning the pre-constructed maps were as effective as in individual learning. The finding from this paper paved way for further research in cognitive development of the students while learning through concept maps. The article suggested that the teachers should adopt the use of concept mapping into their teaching strategy, promoting construction of the maps by the students or using pre-constructed maps.

Brown (2003), used Concept maps along with the idea of constructivism in creating map in groups. The paper states that group mapping allows several ways of learning like mistakes done by the students can show where they lack in understanding, it involves interaction of students with one another leading to constructivist approach and lastly those students who have failed to understand can learn from those who have understood the topic via social interactions. The study had an experimental group and a control group who differed in construction and non-construction of concept map respectively. In the experimental group, further 
division was made where the concept map structure was individual and one involved group construct of concept map. The results from the study showed that the students who constructed concept map in groups outperformed those who constructedindividually or those who didn't construct the concept maps. This was because once the map was constructed the group members can observe, discuss and agree, or modify the concept map and its explanation before returning it for grading. The paper also gives the feedback of the student where the student express that these construction of map are like jigsaw puzzles.

Sharma (2014), conducted an experimental study to check the effectiveness of concept mapping on students ability to understand and retain concepts of organic chemistry. The study was done on class 12 students of CBSE board. The students were divided into two groups, experimental, and control group. Within these groups, the students were divided based on their performance- high achievers and low achievers. The concept of phenols is taught with the help of concept mapping to the experimental group whereas the control group is taught with lecture method. A pre-test, posttest and delayed post-testwere done to determine the achievement and retention of the concept. It was observed that the experimental group showed significantly higher scores when compared to control group. High achievers were able to score better with retention when compared to low achievers. The paper suggests that the concept map would help the teachers to identify the cause of under-achievement among students and also as a misconception correction tools.

Gerstner and Bogner (2009), conducted a study which deals with the application of concept maps in teaching and learning of science. One hundred and forty-nine students were selected from the secondary school in Germany. The students were split in two groups one which had teacher-centric instruction and the other which had student-centric instruction. Both the groups were subjected for concept map construction. The concept maps were analyzed for qualitative tests and students understanding and retention was checked with multiple-choice question (pre-test, post-test and delayed retention test). Test scores were analyzed using ANOVA and t-test. It was observed that the type of teaching 
had an effect on the concept map construction; students of teachercentered approach produced more net-diagrams than those who took part in student-centered.

Eppler (2006), the author compares the concept mapping with other visualization formats like mind mapping, conceptual diagrams, and visual metaphors. The parameters for application and advantages of respectiveformatsare discussed in this article. The authors chose a sample from undergraduate and postgraduate students. This experimental study was able to differentiate students based on the different learning styles. The article suggests that a mixed-mode of visualization, which involves the combination of strong point of the four methods, mentioned above.

The present study was done to check the effectiveness of the concept mapping strategy to detect the concept understanding and concept retention in high school students. As a B.Ed Student, the author wanted to know the use of concept map strategy in regular classroom. Therefore the study is tried out with a small sample of students. This study was conducted in tutorials with nine students. The syllabus in focus was an extract of a chapter titled "structure and function of DNA" from a State Board syllabus textbook.

\section{Objectives of the Study:}

- To develop A concept map Of Structure and function of DNA using a software called C-maps.

- To study the effectiveness of concept mapping strategy in knowledge and retention of DNA concept.

\section{Hypothesis:}

Null Hypothesis $\left(\mathrm{H}_{0}\right)$ : There is no significant difference in pre-test and post-test of DNA concept of $10^{\text {th }}$-grade students.

Hypothesis $1\left(\mathrm{H}_{1}\right)$ : There is significant difference in the pre-test and post-test results of the students. 


\section{Experimental Procedure:}

The experiment conducted was a pilot study with only a experimental group $(n=9)$. It was carried out in a tutorial aka Coaching Centre for Excellence. The average age of students was 14 years.

The experiment was undertaken in four stages, as follows:

Pre-testing: The students were given a set of questions related to the concept to check their knowledge regarding the same. This was an achievement test done for students. The test consisted of 12 question, and the total marks were given out of 15 marks.

Intervention stage: The concept map was created using the software C-map by the investigator. The created concept map was used to teach the students the concept of DNA.

The development of the concept involved selecting a concept from the prescribed textbook of State Board of Karnataka. The concept selected was the Structure and function of DNA (Deoxyribose Nucleic Acid). This was a sub-topic from the Chapter Heredity. The construction of the concept was done in the following steps.

1. The fundamental concept was identified and listed out.

2. The concepts underlining the key concepts was identified and listed out. All the concepts listed out were arranged in hierarchical pattern.

3. The concepts were mapped with the key concept on top, and the other concept was spread hierarchically below the key concept.

4. The different concepts were inter-linked using a suitable links with prepositions. The prepositions were chosen carefully to bring out the relationship between the concepts. 
The following is the concept map [Figure 1] for the concept Structure and function of DNA.

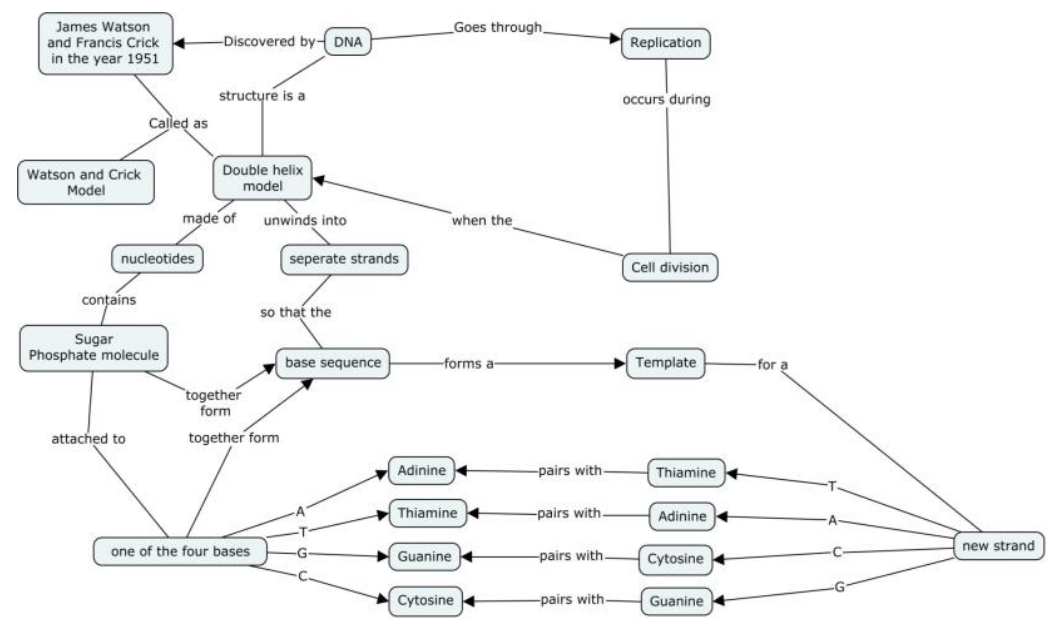

Fig 1

Post-testing: The teaching of concept map was done in a class of 70 minutes duration. After teaching an achievement test was administered to check the level of understanding of the concept by the students.

Delayed post-testing: After a gap of one week an achievement test was administered to check the concept retention.

\section{Analysis and Interpretation of the Data:}

The results of the pre-testing, post-testing and Delayed post-testing were as follows, with the calculation of mean.

Table 1

\begin{tabular}{cccc}
\hline & & & Delayed Post-test \\
Scores of & Pre-test scores & Post-test scores & scores \\
Mean & 1.56 & 10.22 & 5.44 \\
\hline
\end{tabular}

Though the mean and median are almost equal, because the sample number is less than 30, the investigator chose non-parametric data analysis. Based on the different non-parametric data analysis available the researcherdecided to perform Wilcoxon test. The 
analysis done should show the difference between the two subsamples between two related samples. As shown in the Figure 2 below (Cohen et al., 2007) the investigator chose to perform Wilcoxon test.

The analysis was done using the IBM SPSS Statistics Software. Data was analyzed as follows:

- Wilcoxon test was perform with the data of pre-test scores and post-test scores, as these two scores carried out on the same day with same test of students but before and after the treatment. Hence they are related.

- Interclass correlation test was done between the posttest and delayed post-test to check the reliability of the intervention.

Wilcoxon Test Results:

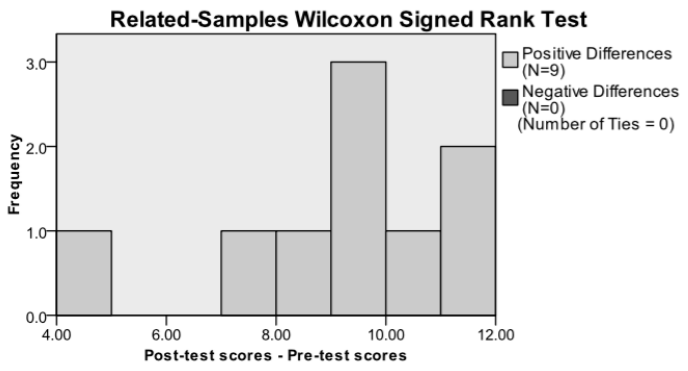

Fig 2

\begin{tabular}{|c|c|c|c|c|}
\hline \multicolumn{5}{|c|}{ Hypothesis Test Summary } \\
\hline & Null Hypothesis & Test & Sig. & Decision \\
\hline & $\begin{array}{l}\text { The median of differences } \\
\text { between Pre-test scores and } \\
\text { Post-test scores equals } 0 \text {. }\end{array}$ & $\begin{array}{l}\text { Related-Samples } \\
\text { Wilcoxon Signed Rank } \\
\text { Test }\end{array}$ & .007 & $\begin{array}{l}\text { Reject the null } \\
\text { hypothesis. }\end{array}$ \\
\hline & $\begin{array}{l}\text { The distributions of Pre-test } \\
\text { scores and Post-test scores } \\
\text { are the same. }\end{array}$ & $\begin{array}{l}\text { Related-Samples } \\
\text { Friedman's Two-Way } \\
\text { Analysis of Variance by } \\
\text { Ranks }\end{array}$ & .003 & $\begin{array}{l}\text { Reject the null } \\
\text { hypothesis. }\end{array}$ \\
\hline
\end{tabular}


From the above results, it is observed that the null hypothesis can be rejected, as there is a significant difference between the pre-test scores and post-test scores.

\section{Interclass Correlation Test}

Table 2- Intra class Correlation Coefficient

\begin{tabular}{|c|c|c|c|c|c|c|}
\hline & \multirow[t]{2}{*}{$\begin{array}{l}\text { Intra class } \\
\text { Correlation }^{b}\end{array}$} & \multicolumn{2}{|c|}{$\begin{array}{l}\text { 95\% Confidence } \\
\text { Interval }\end{array}$} & \multicolumn{3}{|c|}{$\begin{array}{c}\text { F Test with True } \\
\text { Value } 0\end{array}$} \\
\hline & & $\begin{array}{l}\text { Lower } \\
\text { Bound }\end{array}$ & $\begin{array}{l}\text { Upper } \\
\text { Bound }\end{array}$ & Value & df1 & df2 \\
\hline $\begin{array}{l}\text { Single } \\
\text { Measures }\end{array}$ & $.555^{a}$ & -.119 & .879 & 3.491 & 8 & 8 \\
\hline $\begin{array}{l}\text { Average } \\
\text { Measures }\end{array}$ & $.714^{\mathrm{c}}$ & -.270 & .935 & 3.491 & 8 & 8 \\
\hline
\end{tabular}

\begin{tabular}{lcc}
\hline & F Test with True Value 0 & \\
& Sig & \\
Single Measures & & $.048^{\mathrm{a}}$ \\
Average Measures & $.048^{\mathrm{c}}$ \\
\hline
\end{tabular}

Two-way mixed effects model where people effects are random and, measures effects are fixed.

a. The estimator is the same, whether the interaction effect is present or not.

b. Type $\mathrm{C}$ intraclass correlation coefficients using a consistency definition-the between-measure variance is excluded from the denominator variance.

c. This estimate is computed assuming the interaction effect is absent because it is not estimable otherwise.

From the above, it is seen that the significance value of the test is less than 0.05 . This shows the reliability of the posttest and delayed posttest. Hence we can interpret that the retention of concept was seen among the students.

\section{Discussion of the Results:}

The results of the study show that there isan understanding of the concept by the students. This canbe seen with a significance difference seen between pre-test and post-test. The students show 
the retention of the concept and this can be observed through the difference between pre-test and the delayed post-test scores. The result of the study is in agreement with Sharma (2014), Chiou (2008), Bantar (2007).

\section{Conclusion:}

Based on this minimal study, it can be concluded thatconceptmapping strategy is an effective method to create an understanding and retention of the concept for the topic Structure and function of DNA, from the Class 10 State board syllabuses. The study showed similarity to the one conducted by Sharma (2014), where a concept of phenols was taught to $12^{\text {th }}$ standard students using concept maps.

\section{References:}

Bantanur, V. (2007). "Effect of Concept Mapping Strategy in Chemistry on Achievement and Attitude of VIII Standard Students." M.Ed. Dissertation, Karnataka University, Dharwad.

Brown, D.C. (2003). "Hight School Biology: A group approach to Concept Mapping." The American Biology Teacher, 65(3): 192-197.

Chiou, Chei-ChanG. (2008). "The Effect of Concept Mapping on Students' Learning Achievements and Interests." Innovations in Education and Teaching International,45(4), 375-387.

Cohen L., Manion L. and Morrison., K.(2007)."Research Methods in Education" Sixth edition. Taylor \& Francis e-Library, 589.

Eppler, M.J. (2006). "A comparison between concept maps, minds maps, conceptual diagrams, and visual metaphors as complementary tools for knowledge construction and sharing." Information visualization, 5: 202-210.

Gerstner, S and Bogner, X.F. (2009). "Concept map Structure, gender and teaching methods: an investigation of students' science learning." Educational Research, 51(4): 425-438.

How a qualitative approach to concept map analysis can be ... (n.d.). Retrieved from https://www.kcl.ac.uk/ study/ learningteaching/kli/research/pres-pubs/c-mapping/Ed Johnson-Laird, P. N. (1983). "Mental Models."Cambridge: Cambridge University Press. 
Jonassen, D. H., Reeves, T., Hong, N., Harvey, D. and Peters, K. (1997). 'Concept mapping as cognitive learning and assessment tools', Journal of Interactive Learning Research, 8, 3-4, 289-308.

Kinchin, I.M. and Hay, D. B. (2000). "How a qualitative approach to concept map analysis can be used to aid learning by illustrating patterns of conceptual development" Educational Research. 42 (1): $43-57$

Nesbit, J.C andAdesope, O.O. (2006). "Learning with Knowledge and Concept Maps: A Meta-Analysis." Review of Educational research, 76: 413-448.

Novak, J.D and Gowin, D.B. (1996). "Learning how to learn." Cambridge, England: Cambridge University Press.

Sharma K,. (2014). "Effectiveness of Concept Mapping Strategy on Student's Achievement and Concept retention in Organic Chemistry." Indian Educational Review, 52(1): 111-127.

Sharma K,.(2014). "Effectiveness of Concept Mapping Strategy on Student's Achievement." Indian Educational Review, 52(1): 111127. 